\title{
Sub-lethal concentrations of monocrotophos affect aggressive behavior of the fishes Astyanax altiparanae Garutti \& Britski (Teleostei, Characidae) and Oreochromis niloticus (Linnaeus) (Teleostei, Cichlidae)
}

\author{
André Luis da Cruz ${ }^{1}$
}

\begin{abstract}
This study investigated the effects of sublethal concentrations of the pesticide monocrotophos (organophosphate) on the agonistic behavior of two fishes species, Astyanax altiparanae Garutti \& Britski, 2000 (lambari) and Oreochromis niloticus (Linnaeus, 1758) (Nile tilapia). Sublethal concentrations of the pesticide for the two species were determined and lambari was more resistant than Nile tilapia. The sublethal concentrations were smaller than $400 \mathrm{mgl}^{-1}$ for lambari and $20 \mathrm{mgl}^{-1}$ for Nile tilapia. The two species were tested in grouping conditions (triads) and isolation, under monocrotophos concentrations of $200 \mathrm{mgl}^{-1}$ for lambari and $5 \mathrm{mgl}^{-1}$ for Nile tilapia. The concentration decreased the aggressiveness in lambari, but in Nile tilapia an opposite effect was detected. The results show a species-specific effect of the monocrotophos on aggression.

KEY WORDS. Teleostei, Astyanax altiparanae, Oreochromis niloticus, aggressive behavior, organophosphate, monocrotophos, sub-lethal concentrations
\end{abstract}

The interest to investigate water pollutants increased considerably in the last decades. Many of these products are so hard that may kill many organisms when spread through natural waters (LLOYD 1992). These effects, however, are only a part of a more intense picture going on. Sub-lethal concentrations of these pollutants may be promoting intense alterations on several biochemical, physiological and behavioral processes of the organisms (SANTHAKUMAR et al. 2000). Such effects are of indubitable importance since, as a consequence, the population structure may also be disrupted.

Aggressive behavior was investigated mainly because of its importance to the animal's life and its neuro-hormonal background, since the pesticides act on such pathways (LITTLE et al. 1990; THANGNIPON et al. 1995). Moreover, effect of pesticides on the nervous system may affect several processes which, in turn, may modulate emission of aggressive patterns (e.g., pain, blood pressure, gastrintestinal motility etc) (BLAXTER \& HALLERS-TJABBES 1992; PAVLOV et al. 1992).

The present investigation was carried out in two fish species, the characidae lambari, Astyanax altiparanae (GARUTTI \& BRITSKI 2000) and the cichlidae Nile tilapia, Oreochromis niloticus (Linnaeus, 1758). The lambari is a natural fish from neotropical ichthyofauna (GÉRY 1977) and the Nile tilapia was introduced in the Brazil some decades ago (CESP 1985).

1) Rua Teodoro Demonte 268, ap. 12, 15091-260 São José do Rio Preto, São Paulo, Brasil. E-mail: ajcruz@starmedia.com 
Despite aggression may be somehow disruptive, this characteristic is also an important evolved aspect for grouping behavior. Aggression allows territoriality (SHPIGEL \& FISHELSON 1991) and all the derived resources (KAUFMANN 1983). Low aggressive rate, however, may decrease competitive ability and flight capacity (FERNÖ 1987). Therefore, intensification or decreasing on intraspecific aggression may result in less adaptive behaviors. The two species concerned in the present study show evident aggressive behavior, Oreochromis niloticus (ALVARENGA \& VOLPATO 1995; GIAQUINTO \& VOLPATO 1997; BARKI \& VOLPATO 1998) and Astyanax altiparanae (= A. bimaculatus) (SAZIMA 1977).

The present study investigated the effect of monocrotophos, a pesticide still used in agriculture, on aggressive behavior of these two species (lambari and Nile tilapia). A preliminary study was need to describe the aggressive patterns of the lambaris whereas the aggressive ethogram for the Nile tilapia was based on ALVARENGA \& VOLPATO 1995. In a second step, sub-lethal concentrations of monocrotophos were identified for each species, and thus a last experiment tested the effect of such concentrations on the aggressive behavior.

\section{MATERIAL AND METHODS}

\section{Sublethal concentration test}

Astyanax altiparanae were provided by a fish farm located at Penápolis, São Paulo, Brazil. Fish were maintained in a 2000-L tank (1 fish. $\left.20 \mathrm{~L}^{-1}\right)$. Oreochromis niloticus were obtained from CESP Aquaculture Station, Barra Bonita, São Paulo and hold in a $2000-\mathrm{L} \operatorname{tank}\left(1 \mathrm{fish} .10 \mathrm{~L}^{-1}\right)$. The two species were so maintained for 10 days before the experiment. Both species were under a 12-h photoperiod, water temperature $23 \pm 1^{\circ} \mathrm{C}$, and continuous aeration with a biological filter. Commercial food was daily provided (3\% of biomass).

The basic design consisted of exposing the fish to different concentrations of the pesticide monocrotophos [dimethyl-(E)-1-methyl-2-(methylcarbamoyl)vinyl phosphate, Nuvacron 400, Ciba Geigy] and quantification of mortality during $96 \mathrm{~h}$ (THANGNIPON et al. 1995).

Each fish was isolated in a plastic circular aquaria $(\varnothing=10 \mathrm{~cm}$ and $22 \mathrm{~cm}$ high; 1 liter of water) and submitted to the pesticide (or control). Continuous aeration, daily feeding (3\% biomass) and 12 -h photoperiod was provided. Water temperature oscillated from $22.07 \pm 2.26^{\circ} \mathrm{C}$ to $22.85 \pm 2.07^{\circ} \mathrm{C}$ to A. altiparanae and $23.71 \pm 2.9^{\circ} \mathrm{C}$ to $24.14 \pm 2.88^{\circ} \mathrm{C}$ to $O$. niloticus; mean total body length was $6.53 \pm 0.57 \mathrm{~cm}$ and $6.23 \pm$ $0.90 \mathrm{~cm}$, respectively, and there was no significant difference in size between fish from different concentrations of pesticide in a same species (Anova, $p>0.05$ ).

From a pilot study, the test concentrations (mg of Nuvacron $400 . \mathrm{L}^{-1}$ ) were setup for each species: A. altiparanae: 0, 2, 4, 8, 16, 40, 80, 120, 160, 180, 200 and 240, O. niloticus: $0,1.2,2,4,8,16,80,160$. Five fish were tested in each concentration. The pesticide was added to the water of the aquarium before introducing the fish. Observations were developed from 8:00 to 18:00 h every day and death were registered. Data analyses consisted to find the highest tested concentration in which no fish died in $96 \mathrm{~h}$. 


\section{Effect of sublethal concentration of monocrotophos on aggressive behavior}

The fish were provided from the same source as in the previous study. Holding conditions were the same, except the time of holding that is specified for each experiment.

Based on the previous study, the following concentrations of the pesticide were used to assure no pesticide-caused mortality during the tests: $80 \mathrm{mgl}^{-1}$ for $A$. altiparanae and $2 \mathrm{mgl}^{-1}$ for $O$. niloticus. Each species was submitted to the pesticide or pure water (control), with 6 repetition in each condition.

The experiments consisted of submitting the fish to the pesticide (or pure water) and observation of aggression each day for five subsequent day (triad test) or in the first and the fifth day (mirror test). Aggression was inferred from confrontations between the fish in a same triad (triad test) or its image in the mirror (mirror test). The frequency of confrontations was counted irrespectively to the agonistic type. Water quality in terms of ammonia $\left(<0.5 \mathrm{mgl}^{-1}\right)$ and nitrite $(<0.05$ $\mathrm{mgl}^{-1}$ ) was adequate.

\section{Triad tests}

In A. altiparanae, the mean total length of the fish was $6.09 \pm 0.74 \mathrm{~cm}$ (similar size for control and test conditions, $\mathrm{p}>0.05$ ) and the fish were tested after 2 days in the holding condition. In $O$. niloticus the size averaged $6.38 \pm 0.97 \mathrm{~cm}$ (similar between conditions, $\mathrm{p}>0.05$ ) and tests started after seven days in the holding condition.

The fish were introduced into the aquaria in the morning and their behavior video recorded for the following $10 \mathrm{~min}$ and then for another 10 -min period in the afternoon (about $6 \mathrm{~h}$ later). In the successive four days the fish were videos recorded in the morning and afternoon, but for a short period $(5 \mathrm{~min})$.

\section{Mirror test}

The fish were obtained from the same stock. Fish size was similar between control and pesticide conditions for each species ( $\mathrm{p}>0.05$ ). Mean total length was $6.93 \pm 0.69 \mathrm{~cm}$ and $6.68 \pm 1.26 \mathrm{~cm}$ for A. altiparanae and $O$. niloticus, respectively.

The fish were isolated in a glass aquarium $\left(14 \times 11.5 \times 18.5 \mathrm{~cm}^{3}\right)$ with pesticide or pure water, as in the previous study. After three minutes, a mirror was placed outside the smaller wall of the aquarium and fish behavior video was recorded for five minutes from the first bite. The latency to the first bite was quantified. If no bite occurred in $10 \mathrm{~min}$, the session was finished. Video analyses consisted of counting the number of bites the fish emitted to the mirror. Each condition (pesticide and control) was investigated in 10 fish for each species. This test was performed in the first day, immediately the fish was placed into the aquaria, and 96 hours later on, always in the morning.

\section{RESULTS}

\section{Sublethal concentration test}

Figure 1 shows the mortality in the resistance test for the two investigated species, A. altiparanae and $O$. niloticus. Clearly, these two species are resistant to 
monocrotophos in concentrations up to $120 \mathrm{mgl}^{-1}$ and $4 \mathrm{mgl}^{-1}$, respectively. Thus, in the following test of effect of monocrotophos on aggression we chose the second higher concentration where no death ocurred, i. e., $8 \mathrm{mgl}^{-1}$ and $2 \mathrm{mgl}^{-1}$ for $A$. altiparanae and $O$. niloticus, respectively.

Astyanax altiparanae

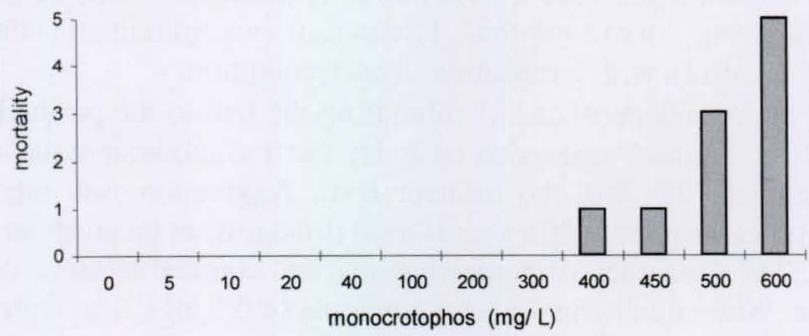

Oreochromis niloticus

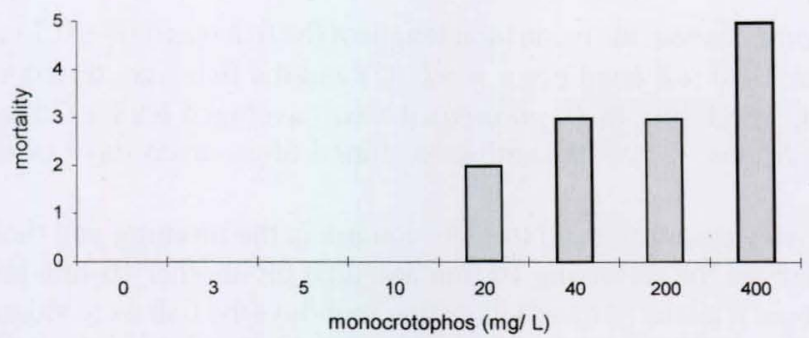

Fig. 1. Mortality during the test of resistance ( $96 \mathrm{~h}$ ) to monocrotophos. Data from five animals in each concentration.

\section{Effect of sublethal concentration of monocrotophos on aggressive behavior}

\section{Astyanax altiparanae}

In the control condition, all the triads showed fights from the first video recording (morning of the first day) to the end of observations. In the test triads, however, four triads showed any type of aggression in the first recording (morning) and five triads fought in the second recording (afternoon of the first day). Only one triad of the test condition did not fought over the 5 days of observations.

Latency to the first fight averaged $107.66 \pm 75.00 \mathrm{~s}$ (from 6 to $202 \mathrm{~s}$ ) and $158.83 \pm 202.76 \mathrm{~s}$ (from 80 to $539 \mathrm{~s}$ ) for control and test conditions, respectively, with no significant difference (Student t test, $\mathrm{p}=0.57$ ).

Confrontations in triads are expressed in figure $2 \mathrm{~A}$. Accordingly, in the first day of the aggression test no significant difference occurred between control and test fish. However, from the third day, the pesticide decreased aggression in relation to the first day $(\mathrm{p}<0.01)$. Compared to the control group, a lower aggression in the test fish was detected from the second day to the end of the experiment $(p<0.01)$. 
In the mirror test, 7 out of 10 fish showed fights directed to their own image in both control and test conditions (Fig. 2B). These fish delayed $10.44 \pm 13.73 \mathrm{~s}$ (from 1 to $72 \mathrm{~s}$ ) and $131.70 \pm 190.72 \mathrm{~s}$ (from 3 to $551 \mathrm{~s}$ ), respectively, for the first fight (latency) in the first mirror test. Despite the higher mean frequency in the test groups, no significant difference was found (Student t test, $\mathrm{p}=0.44$ ).

Astyanax altiparanae - TRIADS

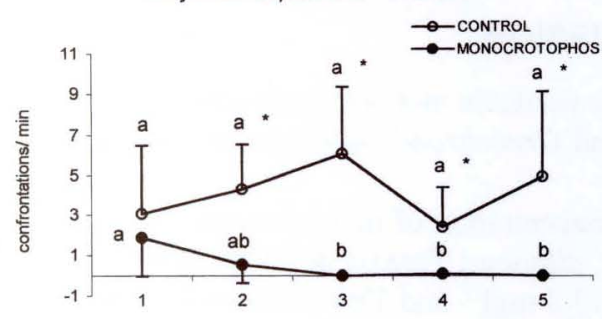

Astyanax altiparanae - MIRROR TEST

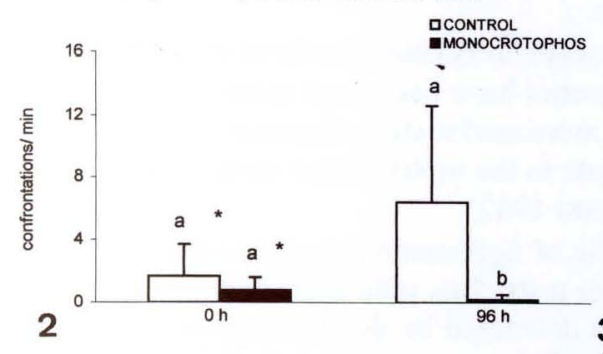

Oreochromis niloticus- TRIADS

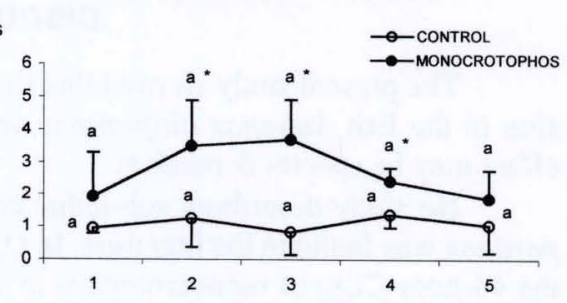

Oreochromis niloticus - MIRROR TEST

口CONTROL - MONOCROTOPHOS

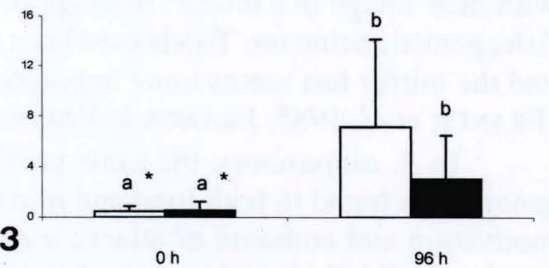

Figs 2-3. Mean confrontations rate ( $\pm \mathrm{sd}$ ) of (2) Astyanax altiparanae from monocrotophos (80 $\mathrm{mg} / \mathrm{l}$ or control groups) and (3) Oreochromis niloticus from monocrotophos (2 mg/l or control groups). (A) Asterisks indicate significant differences between groups (Kruskal-Wallis, $n=6$ ) and means in a same group with at least a same lower case letter shows no significant difference (Friedman); (B) Mean values from individual fish ( $n=10$ each group) in two periods ( 0 h started pesticide contact). Asterisks indicate significant differences between periods in a same group (Wilcoxon) and different lower case letter shows significant difference in a same period (Mann-Whitney). $P$ values for both graphs are in the text.

\section{Oreochromis niloticus}

In the control condition, only four triads showed fight in the first video recording (morning of the first day), but all of them fought in the successive periods of observation. In the test triads, however, all the triads showed fight in all the observation periods.

Latency to the first fight averaged $216.00 \pm 205.70 \mathrm{~s}$ (from 140 to $518 \mathrm{~s}$ ) and $234.00 \pm 180.06 \mathrm{~s}$ (from 125 to $509 \mathrm{~s}$ ) for control and test conditions, respectively, with no significant difference (Student t test, $\mathrm{p}=0.87$ ).

Fight frequency in triads are presented in figure $3 \mathrm{~A}$. Despite no significant change of fight frequency occurred in a same condition over time (control: $p=0.57$, test: $p=0.08)$, the test fish significantly showed higher confrontation frequency from the second to the fourth day compared to the control fish $(\mathrm{p}<0.05)$. 
In the mirror test, all the 10 fish showed fights directed to the mirror in the test condition (Fig. 3B). However, only 6 out of 10 control fish showed any type of fighting in the first day. These fish delayed $50.77 \pm 81.45 \mathrm{~s}$ (from 3 to $344 \mathrm{~s}$ ) and $179.00 \pm 206.48 \mathrm{~s}$ (from 2 to $476 \mathrm{~s}$ ), respectively, for the first fight (latency) in the first mirror test. Despite the higher mean frequency in the test groups, no significant difference was found (Student $\mathrm{t}$ test, $\mathrm{p}=0.21$ ).

\section{DISCUSSION}

The present study showed that the pesticide monocrotophos affects aggression in the fish Astyanax altiparanae and Oreochromis niloticus and that a such effect may be species dependent.

No study describing sub-lethal concentration of monocrotophos in A. altiparanae was found in the literature. In O. niloticus, TEJADA \& BAJET (1990) found the 48-hour CL50 of monocrotophos in $13.8 \mathrm{mgl}^{-1}$ and THANGNIPON et al. (1995) in $4.9 \mathrm{mg} . \mathrm{L}^{-1}$ for $96 \mathrm{~h}$. Our study showed no mortality of $O$. niloticus in concentration equal to and lower to $4 \mathrm{mgl}^{-1}$.

Aggression was evaluated by two ways, direct confront in triads and contests with their image in a mirror. Both approaches have been used in investigations on fish agonistic behavior. Triads have been more used to study dominance relationship and the mirror test seems more appropriate to the motivational state of aggression (FRANCK et al. 1985; FRANCK \& RIBOWSKI 1987).

In $A$. altiparanae, the same profile of aggression between control and test groups was found in both triad and mirror tests. This indicate that both aggressive motivation and emission of attacks were decreased by the monocrotophos in this species. In O. niloticus, however, this association was not so clear. In the triads the pesticide induced confrontation, but not in the mirror test. An explanation is that the aggressive motivation was not affected, but only the agonistic events (animals may be more responsive to conspecific action and thus more attention was devoted to the other fish).

Monocrotophos inhibits acetylcholinesterase and thus increases excitability in the nervous system of the animals (SKRIPSKY \& LOOSLI 1994). If the effect on aggression described here non derived from this excitatory effect, increasing both mobility and encounter between the oponent, $A$. altiparanae and $O$. niloticus should to show the same response to the pesticide, but this did not occur. Monocrotophos increased confrontations in $O$. niloticus and decreased it in A. altiparanae. This effect on aggression is reinforced since no correlation was detected between number of confrontations and time spent in free swimming. These considerations points to other ways by which the pesticide affected aggression in these two species. SANTHAKUMAR \& BALAJI (2000) observed in Anabas testudineus on exposure to monocrotophos, decrease in opercular movements, loss of equilibrium, increase in surfacing behavior, change in body colour, increase in mucus secretion all over the body, irregular swimming activity, increase in nudge, nip and aggressiveness.

The different effects found in A. altiparanae and $O$. niloticus support the assertion that this is a species-dependent effect of monocrotophos, despite its one-way mechanism of action. How could this effect be species dependent? 
Before complex explanations may be thought out, differences in absortion, metabolization and excretion of the monocrotophos may be considered. Thus, differences in metabolic rate between these two species may give different treatment to this compound into the living fish. Despite such cautionary notes, the opposite effect of monocrotophos on the aggressive behavior of A. altiparanae and $O$. niloticus may also be a consequence of the concentrations used. In A. altiparanae, the sub-lethal concentration employed was higher than that used for $O$. niloticus: in the former, twice the concentration of $80 \mathrm{mgl}^{-1}$ was lethal, but this was not the case in the later $\left(2 \mathrm{mgl}^{-1}\right)$. So, in relative terms, the first concentration may be considered higher to the fish.

The effect of sub-lethal concentrations of monocrotophos on aggression, increasing or decreasing it, may have important ecological consequences. Aggression is a homeostatic behavior for the fish, or even for the intraspecific group, stabilizing hierarchical relationship, territory and predator defense. Changes in aggression may affect these processes and survival may be decreased. Higher intraspecific aggression may increase damage to the animals. Low aggression may decrease territory size and so less resources. These expeculations advise that danger for pollution in rivers are not concentrated in the death of the organism, but also in small changes in their population structure which could affect survival.

ACKNOWLEDGEMENTS: This work was supported by Fundação de Amparo à Pesquisa do Estado de São Paulo (FAPESP n 96/05322-9). The author is grateful to Dr. G.L. Volpato for the supervision and A.C.B. Tardivo for the skilful technical assistance.

\section{REFERENCES}

Alvarenga, C.M.D. \& G.L. Volpato. 1995. Agonistic profile and metabolism in alevins of the Nile tilapia. Physiol. Behav., Oxford, 57: 75-80.

BARKI, A. \& G.L. Volpato. 1998. Early social environment and the fighting behaviour of young Oreochromis niloticus (Pisces, Cichlidae). Behaviour, Leiden, 135: 913-929.

Blaxter, J.H.S. \& C.C. Ten Hallers-TJabBes. 1992. The effect of pollutants on sensory systems and behaviour of aquatic animals. Netherl. Jour. Aquat. Ecol., Amsterdam, 26: 43-58.

CESP. 1985. Criação da Tilápia-do-Nilo. São Paulo, CESP, 12p.

FERNÖ, A. 1987. Aggressive behaviour between territorial cichlids (Astatotilapia burtoni) in relation to rank and territorial stability. Behaviour, Leiden, 103: 241-258.

Franck, D.; R.P. Hannes; H. LANFFERmann \& A. RibowSKi. 1985. Effects of social isolation on aggressiveness in fish with special reference to the swordtail (Xiphophorus helleri). Behav. Proces., Amsterdam, 10: 415-427.

FRANCK, D. \& A. RiBOWSKI. 1987. Influences of prior agonistic experiences on aggression measures in the male swordtail (Xiphophorus helleri). Behaviour, Leiden, 103: 217-240.

Garutti, V. \& H.A. Britski. 2000. Descrição de uma espécie nova de Astyanax (Teleostei: Characidae) da bacia do alto rio Paraná e considerações sobre as demais espécies do gênero na bacia. Comum. Mus. Ciênc. Tecnol. PUCRS, Sér. Zool., Porto Alegre, 13: 65-88.

GÉRY, J. 1977. Characoids of the world. Neptune City, T.F.H. Publications, 672p.

Giaquinto, P.C. \& G.L. Volpato. 1997. Chemical communication, aggression and conspecific recognition in the fish Nile tilapia. Physiol. Beh., Oxford, 62: 1333-1338.

KaufmanN, J.H. 1983. On the definitions and functions of dominance and territoriality. Biol. Revue, New York, 58: 1-20. 
LitTle, E.E.; R.D. ARChESKI; B.A. Flerov \& V.A. Kozlovskaya. 1990. Behavioral indicators of sublethal toxicity in rainbow trout. Arch. Environ. Contam. Toxicol., New York, 19: 380-385.

LLOYD, R. 1992. Pollution and freshwater fish. Oxford, Fishing News Books, 176p.

PAvlov, D.D.; G.M. Chuiko; Y.V. Gerassimov \& V.D. TonKopIY. 1992. Feeding behavior and brain acetylcholinesterase activity in bream (Abramis brama L.) as affected by DDVP, na organophosphorus insecticide. Comp. Biochem. Physiol. C, Oxford, 103: 563-568.

Santhakumar, M.; M. Balaji; K.R. Saravanan; D. Soumady \& K. Ramadu. 2000. Effect of monocrotophos on the optomotor bevaviour of an air-breathing fish, Anabas testudineus (Bloch). Jour. Environ. Biol., Lucknow, 21: 65-68.

SANTHAKumar, M. \& M. BaLAJI. 2000. Acute toxicity of an organophosphorus insecticide monocrotophos and its effects on behavior of an air-brathing fish, Anabas testudineus (Bloch). Jour. Environ. Biol., Lucknow, 21: 121-123.

SAZIMA, I. 1977. Possible case of aggressive mimicry in a neotropical scale-eating fish. Nature, London, 270: $510-512$.

SHPIGEL, M. \& L. FISHELSON. 1991. Territoriality and associated behaviour in three species of the genus Cephalopholis (Pisces: Serranidae) in the Gulf of Aqaba, Red Sea. Jour. Fish Biol., London, 38: 887-896.

SKRIPSKY, T. \& R. LoosLI. 1994. Toxicology of monocrotophos, p. 13-39. In: G.W. WARE (Ed). Reviews of Environmental Contamination and Toxicology. New York, Springer-Verlag, Vol. 139, 460p.

Tejada, A.W. \& C.M. Bajet. 1990: Fate of pesticide in rice-fish ecosystem. Philip. Agricultural, Laguna, 73: 153-163.

Thangnipon, W.; W. Thangnipon; P.L. Luangpaiboon; S. Chinabut. 1995. Effects of the organophosphate insecticide, Monocrotophos, on acetylcholinesterase activity in the Nile tilapia fish (Oreochromis niloticus) brain. Neurochem. Research, New York, 20: 587-591.

Received in 13.V.2002; accepted in 23.X.2002. 